\title{
Patient's Rights- Awareness among Indoor Patients of a Tertiary Care Teaching Hospital in Wardha
}

\author{
Rutuj Waghmare ${ }^{1}$, Shobha Joshi² ${ }^{2}$ Pramita Muntode ${ }^{3}$ \\ ${ }^{1}$ Department of Community Medicine, JNMC, Wardha, Maharashtra, India. ${ }^{2}$ Department of Community Medicine, \\ JNMC, Wardha, Maharashtra, India. ${ }^{3}$ Department of Community Medicine, JNMC, Wardha, Maharashtra, India.
}

\section{ABSTRACT}

\section{BACKGROUND}

Patient's knowledge about their "disease condition and rights creates a benchmark for effective doctor-patient communication". Informed patients are better aware of their diseases, treatment, and care thus, they should also be made to actively participate in their own care. For these reason health care worker should educate the patient regarding their disease condition.

\section{METHODS}

A cross-sectional study was conducted among 196 indoor patients of a tertiary care teaching hospital of Wardha city using 21 questionnaire based on NABH \& patients right charter. The sampling was done by simple random sampling method. Written inform consent was taken from patients who were admitted as indoor patients and had remained beyond 3 weeks in the hospital. Descriptive analysis was carried out in order to evaluate the measures of the collected result.

\section{RESULTS}

Most of the patients were adults followed by older adults with a percentage of $53.6 \%$ and $34.7 \%$ respectively. The percentages of male and female patients admitted were $45.9 \%$ and $54.1 \%$ respectively. Patients from urban areas were more aware than those from rural areas. Education plays an important role in patients' rights as most of the variables were found to be statistically significant.

\section{CONCLUSIONS}

This study concludes that there is a need for raising knowledge and awareness to educate the patients about their rights. Along with their rights, the patients should know about their responsibilities in the hospital as well.
Corresponding Author: Shobha Joshi, Girls Hostel, Jawaharlal Nehru Medical College, Sawangi (Meghe), Wardha, Maharashtra, India.

E-mail: shobhajoshi101@gmail.com

DOI: $10.14260 / j e m d s / 2020 / 127$

Financial or Other Competing Interests: None.

How to Cite This Article:

Waghmare R, Joshi S, Muntode P. Patient's rights- awareness among indoor patients of a tertiary care teaching hospital in Wardha. J. Evolution Med. Dent. Sci. 2020;9(08):570575, DOI: $10.14260 /$ jemds/2020/127

Submission 08-11-2019, Peer Review 29-01-2020,

Acceptance 04-02-2020,

Published 24-02-2020.

\section{KEY WORDS}

Knowledge, Rights, Patients 


\section{BACKGROUND}

'Health for all' is a mission of World Health Organization (WHO). Universal Declaration (1948), recognizes the 'equal and unalienable rights of the human family' of all members. It is on the basis of this concept of the person, and the all human beings equality, and the fundamental dignity, that the concept of patient rights was developed. ${ }^{1}$ Human fundamental right is a Patients' rights and an excellence of declaration that during the procedures we protect patients from mistreatment, judgment and promotes moral practices. . $^{2-3}$ "Patients' rights" are main part of current healthcare practice. Possibly, inhumanity patients are the most susceptible groups. Hence, enlightening the rights of patients is replicated as importance in the condition of medical amenities and one of the medical indices in society. 4

Patients' rights promotion is the priorities among healthcare providers and is consider as an indicator of the health state in every group of people. Informed patients are better aware of their diseases, treatment, and care thus, they should also be made to actively participate in their own care.56 The World Health Organization also believes that the sole existence of the charter will not lead to optimization of patients' rights. They will be effectively practiced in presence of appropriate policies, collaboration, and public awareness, community empowerment along with development of economic, social, and cultural indices. ${ }^{7}$ Health squad supporters play significant role in the protection and the implementation of "patient's rights", a matter deal with great care in medical ethics. ${ }^{8}$

The physicians and their patient relationship have undergone important changes in recent years. As a medical practitioner should have to always act according to his/her principles, and always for the greatest benefit of the patient, equivalent effort must be made to guarantee patients justice and autonomy. Medical practitioner and other publics or forms involved in the delivery of health care have a combined responsibility to distinguish and implement "patients' rights". 9 The "World Medical Association International Code of Medical Ethics" (1949) has been clarified the duties of medical practitioner, and medical practitioner to respect the patients 'confidences even after death of the patients it is considered among the duties.10 Awareness of Patients' rights are observing in patient that accomplish more satisfaction of the patient, medical doctor, hospital staff and other medical team and that will lead to blowout the good morals among patients and medical team; so ultimately the ethical status will be upgraded of all the individuals such as patients and medical team, otherwise these not observing in provided rights, so that health care team would lead to distrust.(11,12) Lot of advantages can bring to Patients' awareness of privacy and confidentiality such as engorged promotion of patients' health, quality of healthcare services, decreased risk of irreversible physical, and reduced hospital stay, and spiritual damages. ${ }^{13}$ Therefore, patients who entirely belief on physicians will expose friendly and personal information concerning about their health status. In addition to this, keeping patients' issue personal is fundamental to sustain trust of the community in medical specialists and healthcare facilities. An increasing number of studies have investigated the knowledge of patients regarding issues of privacy and confidentiality. Patients have poor awareness of their rights that shown in most of the studies, and some studies have indicated that many patients are either, misunderstand, or unaware of the legal and ethical duty of confidentiality. 14-17 Furthermore, minority of patients distrusts clinicians in terms of confidential information protection and may consequently delay or forgo medical care. ${ }^{18}$ With respect to our review of literature not a single study in central India on this topic so we conduct the study with aim of the assessing: Awareness among indoor patients of a tertiary care teaching hospital in Wardha regarding patients' rights.

\section{METHODS}

It's a cross-sectional study which was conductedfor investigating the Awareness among indoor patients regarding their rights in a tertiary care teaching hospital in Wardha city using questionnaire based interview on 196 indoor patients. The sampling was done by simple random sampling method. Written Inform consent was taken from patients who were admitted in the indoor patients department (IPD) and had remained beyond 3 weeks in the hospital. The study tool used in this study consisted of a questionnaire of 21 questions on the Basis of standards of the "National Accreditation Board for Hospitals and Healthcare Providers (NABH) and patients' charter of rights". Data was collected after providing instructions about how to fill questions and a period of $15-20$ minutes was given for filling and returning the questionnaires. The study participants were subject to the 21 point questionnaire with instructions to respond to each question with 'yes' or 'no'. The participant's demographic detail was also noted like age, gender, education along with the duration of hospital stay, ward in which they were admitted etc. Data was organized and stored in spreadsheet Excel 2007 program for windows XP. By SPSS software version 21 the statistical analysis was done. Frequencies and percentages were depicted Descriptive analysis was carried out in order to evaluate the measures of the collected result. Descriptive statistics and Chi-square test was used to analyze the differences in awareness between sub-groups based on sociodemographic characteristics used in the present study.

\section{RESULTS}

The Demographic characteristics of patients are shown in Table 1. From this we observe that most of the patients are adults (18-35 years) followed by middle age \& older (36-59 year) patients with the percentage of $53.6 \%$ and $34.7 \%$ respectively. The male and female patients admitted were almost same with the percentage of $45.9 \%$ and $54.1 \%$. Education plays most important role in the hospital admission rate. The uneducated and below SSC patients $(23.5 \%, 26.5 \%)$ are more than the SCC, HSC and graduation $(13.3 \%, 11 \%$, $21.4 \%$, respectively). The post graduated patients showed comparatively lower admission rate i.e. only $4.1 \%$ which can be due to good socioeconomic conditions because of that they preferred private hospital than tertiary teaching hospitals. The rural people showed more admission rate than the urban i.e. $61.7 \%$ \& $38.3 \%$. The patients who belongs to rural area they are mostly admitted to general ward due to economic 
condition i.e. about $82.1 \%$. The urban areas patients are admitted in private ward i.e. about $17.9 \%$. The patients staying in hospital since 2-3 weeks showed percentage of $61.2 \%$. Which was comparatively higher than the patients stay in hospital from less than 1 week \& more than 3 weeks i.e. $28.6 \%$ \& $10.2 \%$.

Table 2 compare the educational status of the patients, questions' like doctors name, doctors qualification, approx. Length of stay, health condition, inform about treatment complication, inform plan of care, choose treatment, informed consent, seen the patients' rights board display, right to privacy and confidentiality, inform deposit amount required, informed to submit the details of insurance, all this showed the statistically significant results which ultimately means that the education plays most important role in patients education. Table 3 shows the patients admitted to either general ward or private ward number of patients are admitted to general ward $(n=161)$ compared to these who are admitted to private ward $(n=35)$. There were statically significant found components i.e. doctors' qualification (0.00), inform about treatment complications (0.01) and inform deposit amount required (0.03).

\begin{tabular}{|c|c|c|}
\hline Variables & Number & Percentage \\
\hline \multicolumn{3}{|c|}{ Age } \\
\hline Adolescence (9-17) & 6 & 3.1 \\
\hline Adult (18-35) & 105 & 53.6 \\
\hline Older adult (36-59) & 68 & 34.7 \\
\hline Elderly (60 \&above) & 17 & 8.7 \\
\hline \multicolumn{3}{|c|}{ Gender } \\
\hline Male & 90 & 45.9 \\
\hline Female & 106 & 54.1 \\
\hline \multicolumn{3}{|c|}{ Education } \\
\hline Uneducated & 46 & 23.5 \\
\hline Below SSC & 52 & 26.5 \\
\hline SSC pass & 26 & 13.3 \\
\hline HSC & 22 & 11.2 \\
\hline Graduation & 42 & 21.4 \\
\hline P.G & 8 & 4.1 \\
\hline \multicolumn{3}{|c|}{ Marital Status } \\
\hline Unmarried & 48 & 24.5 \\
\hline Married & 102 & 52 \\
\hline Divorced & 15 & 7.7 \\
\hline Widow & 31 & 15.8 \\
\hline \multicolumn{3}{|c|}{ Place of Residence } \\
\hline Rural & 121 & 61.7 \\
\hline Urban & 75 & 38.3 \\
\hline \multicolumn{3}{|c|}{ Ward } \\
\hline General & 161 & 82.1 \\
\hline Private & 35 & 17.9 \\
\hline \multicolumn{3}{|c|}{ Duration of Stay } \\
\hline Below 1 week & 56 & 28.6 \\
\hline Between 2-3 weeks & 120 & 61.2 \\
\hline More than 3 weeks & 20 & 10.2 \\
\hline \multicolumn{3}{|c|}{ Table 1. Demographic Details of Participants } \\
\hline
\end{tabular}

Table 4 from that we observe that most of patients knows their treating doctor name $(80.6 \%)$ but the qualification of doctor is not known among almost half of the admitted patients (49\%),same results are noted in case of almost 50.5\% of patients, they did not know the appears length of stay in hospital. Results also conclude that most of the patients know about their current health condition (67.9\%) \&expected treatment cost $(60.2 \%)$.About half of the patients know the treatment complication (52.6\%) \& most of the patients knows plan of care $(64.8 \%)$.About $65.8 \%$ of patients was not knows health prognosis. The $51.5 \%$ patients were not seen the patients' rights board. The $60.2 \%$ of patients were not known the rights to privacy and confidentiality. Only $38.3 \%$ of patients were known about treatment feedback process and about half the patients were not knowing about the complaints of treatments process (55.1\%). The one third of patients were knows the inpatients charge $(72.4 \%)$, same results noted in the deposit amount required (74.5\%).about half of the patients were not known about the submit details of insurance (50.5\%).only $39.3 \%$ of patients were knows about the administrated medication. The $55.1 \%$ of patients are aware about healthcare infection and its prevention. Only $17.1 \%$ patients were not aware about diet counselling. Our results conclude that $100 \%$ of patients that they must be educated about their rights \& prevents their fall.

\begin{tabular}{|c|c|c|c|c|c|c|c|c|c|c|c|c|c|c|}
\hline \multirow{3}{*}{$\begin{array}{l}\dot{0} \\
\dot{z} \\
\dot{5}\end{array}$} & \multirow{3}{*}{ 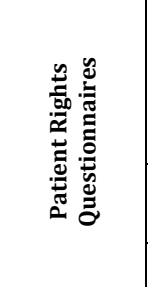 } & \multicolumn{2}{|c|}{ 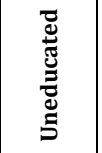 } & \multicolumn{2}{|c|}{ 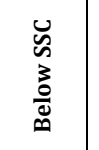 } & \multicolumn{2}{|c|}{$\ddot{\mathscr{s}}$} & \multicolumn{2}{|r|}{ ũ } & \multicolumn{2}{|c|}{ 节 } & \multicolumn{2}{|r|}{ بّ بـ } & \multirow{3}{*}{ ڤั) } \\
\hline & & \multicolumn{2}{|c|}{$\stackrel{0}{11}$} & \multicolumn{2}{|c|}{$\stackrel{\text { \๊ }}{\text { II }}$} & \multicolumn{2}{|c|}{ 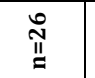 } & \multicolumn{2}{|r|}{$\stackrel{N}{\Perp}$} & \multicolumn{2}{|c|}{ 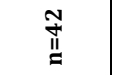 } & \multicolumn{2}{|c|}{$\stackrel{\infty}{\Perp}$} & \\
\hline & & z & de & $=$ & o & $=$ & o & $=$ & o & $=$ & o & $=$ & $\partial^{0}$ & \\
\hline 1 & $\begin{array}{l}\text { To know the } \\
\text { doctors name }\end{array}$ & 29 & 63 & 41 & 78.84 & 24 & \begin{tabular}{|l|l|}
92.3 & 2
\end{tabular} & 20 & 90.9 & 38 & 90.47 & 6 & 75 & 0.57 \\
\hline 2 & $\begin{array}{l}\text { To know the } \\
\text { doctor's } \\
\text { qualification }\end{array}$ & 12 & 26 & 21 & 40.38 & 12 & 46.15 & 15 & 68.18 & 35 & 83.33 & 5 & 62.5 & 0.62 \\
\hline 3 & $\begin{array}{c}\text { To know the } \\
\text { approx. length } \\
\text { of stay }\end{array}$ & 20 & 43.48 & 18 & 34.61 & 10 & 38.46 & 15 & 68.18 & 30 & 71.42 & 4 & 50 & 0.57 \\
\hline 4 & \begin{tabular}{|c|}
$\begin{array}{c}\text { To know the } \\
\text { expected } \\
\text { treatment cost }\end{array}$ \\
\end{tabular} & 23 & 50 & 26 & 50 & 16 & \begin{tabular}{|l|l}
61.53 \\
\end{tabular} & 13 & 59.09 & 33 & 78.57 & 7 & 87.5 & 0.29 \\
\hline 5 & $\begin{array}{l}\text { To know the } \\
\text { health } \\
\text { condition }\end{array}$ & 21 & 45.65 & 37 & 71.15 & 14 & 53.84 & 17 & 77.27 & 37 & 88.09 & 7 & 87.5 & 0.21 \\
\hline 6 & \begin{tabular}{|c|} 
To be informed \\
about \\
treatment \\
complication \\
\end{tabular} & 15 & 32.6 & 22 & 42.3 & 14 & 53.84 & 14 & 63.63 & 31 & 73.8 & 7 & 87.5 & 0.4 \\
\hline 7 & $\begin{array}{c}\text { To be informed } \\
\text { plan of care }\end{array}$ & 18 & 39.13 & 30 & 57.69 & 20 & 76.92 & 16 & 72.72 & 35 & 83.33 & 8 & 100 & 0.6 \\
\hline 8 & \begin{tabular}{|l|} 
To choose \\
treatment
\end{tabular} & 13 & 28.26 & 20 & 38.46 & 8 & 30.76 & 11 & 50 & 26 & 61.9 & 3 & 37.5 & 0.02 \\
\hline 9 & $\begin{array}{c}\text { To give } \\
\text { informed } \\
\text { consent }\end{array}$ & 16 & 34.78 & 24 & 46.15 & 8 & 30.76 & 7 & 31.81 & 26 & 61.9 & 5 & 62.5 & 0.04 \\
\hline 10 & \begin{tabular}{|c|}
$\begin{array}{c}\text { To know health } \\
\text { prognosis }\end{array}$ \\
\end{tabular} & 11 & 23.91 & 19 & 36.53 & 6 & $23.07 \mid$ & 8 & 36.36 & 19 & 45.23 & 4 & 50 & 0.22 \\
\hline 11 & $\begin{array}{c}\text { Seen the } \\
\text { patients' rights } \\
\text { board displayed }\end{array}$ & 15 & 32.6 & 32 & 61.53 & 10 & 38.46 & 9 & 40.9 & 29 & 69.04 & 6 & 75 & 0.01 \\
\hline 12 & $\begin{array}{c}\text { Right to privacy } \\
\text { and } \\
\text { confidentiality } \\
\text { of patient } \\
\text { information }\end{array}$ & 12 & 26 & 19 & 36.53 & 9 & $34.61 \mid$ & 9 & 40.9 & 24 & 57.14 & 5 & 62.5 & 0.04 \\
\hline 13 & $\begin{array}{c}\text { To give } \\
\text { feedback about } \\
\text { treatment } \\
\text { process }\end{array}$ & 18 & 39.13 & 20 & 38.46 & 12 & 46.15 & 7 & 31.81 & 16 & 38.09 & 2 & 25 & 0.89 \\
\hline 14 & \begin{tabular}{|c|} 
To give \\
complaints of \\
treatment \\
process \\
\end{tabular} & 18 & 39.13 & 25 & 48 & 11 & 42.3 & 10 & 45.45 & 20 & 47.61 & 4 & 50 & 0.95 \\
\hline 15 & $\begin{array}{c}\text { To be informed } \\
\text { about inpatient } \\
\text { charges }\end{array}$ & 29 & 63.04 & 35 & 67.3 & 18 & 69.23 & 15 & 68.18 & 37 & 88.09 & 8 & 100 & 0.04 \\
\hline 16 & $\begin{array}{c}\text { To be informed } \\
\text { deposit amount } \\
\text { required }\end{array}$ & 27 & 58.69 & 37 & 71.15 & 20 & 76.92 & 14 & 63.63 & 40 & 95.23 & 8 & 100 & 0.12 \\
\hline 17 & $\begin{array}{c}\text { To be informed } \\
\text { to submit the } \\
\text { details of } \\
\text { Insurance }\end{array}$ & 12 & 26 & 19 & 36.53 & 14 & 53.84 & 15 & 68.18 & 31 & 73.8 & 6 & 75 & 0.07 \\
\hline 18 & $\begin{array}{c}\text { To know about } \\
\text { the medication } \\
\text { administered }\end{array}$ & 13 & 28.26 & 22 & 42.3 & 9 & 34.61 & 7 & 31.81 & 22 & 52.38 & 4 & 50 & 0.24 \\
\hline 19 & $\begin{array}{c}\text { To be informed } \\
\text { about } \\
\text { healthcare } \\
\text { infection and its } \\
\text { prevention }\end{array}$ & 23 & 50 & 29 & 55.76 & 14 & 53.84 & 11 & 50 & 26 & 61.9 & 5 & 62.5 & 0.88 \\
\hline 20 & \begin{tabular}{|c|}
$\begin{array}{c}\text { To diet } \\
\text { counselling }\end{array}$ \\
\end{tabular} & 32 & 69.56 & 42 & 80.76 & 25 & 96.15 & 18 & 81.81 & 36 & 85.71 & 8 & 100 & 0.06 \\
\hline 21 & $\left|\begin{array}{c}\text { Be educated to } \\
\text { prevent falls }\end{array}\right|$ & 46 & 100 & 52 & 100 & 26 & 1002 & 22 & 100 & 42 & 100 & 8 & 100 & \\
\hline
\end{tabular}




\begin{tabular}{|c|c|c|c|c|c|c|}
\hline \multirow{3}{*}{$\begin{array}{l}\text { Sr. } \\
\text { No. }\end{array}$} & \multirow{3}{*}{$\begin{array}{l}\text { Patient Rights } \\
\text { Questionnaires }\end{array}$} & \multirow{2}{*}{\multicolumn{2}{|c|}{$\begin{array}{l}\text { General } \\
(n=161)\end{array}$}} & \multirow{2}{*}{\multicolumn{2}{|c|}{$\begin{array}{l}\text { Private } \\
(n=35)\end{array}$}} & \multirow{3}{*}{$\begin{array}{c}\text { p- } \\
\text { Value }\end{array}$} \\
\hline & & & & & & \\
\hline & & $\mathbf{n}$ & $\%$ & $\mathbf{n}$ & $\%$ & \\
\hline 1 & To know the doctors name & 128 & 79.5 & 30 & 85.71 & 0.4 \\
\hline 2 & To know the doctor's qualification & 75 & 46.58 & 25 & 71.42 & 0 \\
\hline 3 & To know the approx. length of stay & 78 & 48.44 & 19 & 54.28 & 0.53 \\
\hline 4 & To know the expected treatment cost & 94 & 58.38 & 24 & 68.57 & 0.26 \\
\hline 5 & To know the health condition & 107 & 66.45 & 26 & 74.28 & 0.36 \\
\hline 6 & $\begin{array}{l}\text { To be informed about treatment } \\
\text { complication }\end{array}$ & 78 & 48.44 & 25 & 71.42 & 0.01 \\
\hline 7 & To be informed plan of care & 101 & 62.73 & 26 & 74.28 & 0.19 \\
\hline 8 & To choose treatment & 68 & 42.23 & 13 & 37.14 & 0.57 \\
\hline 9 & To give informed consent & 69 & 42.85 & 17 & 48.57 & 0.53 \\
\hline 10 & To know health prognosis & 57 & 35.4 & 10 & 28.57 & 0.44 \\
\hline 11 & $\begin{array}{l}\text { Seen the patients' rights board } \\
\text { displayed }\end{array}$ & 81 & 50.31 & 20 & 57.14 & 0.46 \\
\hline 12 & $\begin{array}{c}\text { Right to privacy and confidentiality of } \\
\text { patient information }\end{array}$ & 62 & 38.5 & 16 & 45.71 & 0.43 \\
\hline 13 & $\begin{array}{c}\text { To give feedback about treatment } \\
\text { process }\end{array}$ & 64 & 39.75 & 11 & 31.42 & 0.35 \\
\hline 14 & $\begin{array}{c}\text { To give complaints of treatment } \\
\text { process }\end{array}$ & 73 & 45.34 & 15 & 42.85 & 0.78 \\
\hline 15 & $\begin{array}{c}\text { To be informed about inpatient } \\
\text { charges }\end{array}$ & 115 & 71.42 & 27 & 77.14 & 0.49 \\
\hline 16 & $\begin{array}{l}\text { To be informed deposit amount } \\
\text { required }\end{array}$ & 115 & 71.42 & 31 & 88.57 & 0.03 \\
\hline 17 & $\begin{array}{l}\text { To be informed to submit the details } \\
\text { of Insurance }\end{array}$ & 78 & 48.44 & 19 & 54.28 & 0.53 \\
\hline 18 & $\begin{array}{l}\text { To know about the medication } \\
\text { administered }\end{array}$ & 64 & 39.75 & 13 & 37.14 & 0.77 \\
\hline 19 & $\begin{array}{l}\text { To be informed about healthcare } \\
\text { infection and its prevention }\end{array}$ & 89 & 55.27 & 19 & 54.28 & 0.91 \\
\hline 20 & To diet counselling & 130 & 80.74 & 31 & 88.57 & 0.27 \\
\hline 21 & Be educated to prevent falls & 161 & 100 & 35 & 100 & \\
\hline & Adm & & . & & & \\
\hline
\end{tabular}

\begin{tabular}{|c|c|c|c|c|c|}
\hline $\begin{array}{l}\text { Sr. } \\
\text { No. }\end{array}$ & Patient Rights Questionnaires & Yes & $\%$ & No & $\%$ \\
\hline 1 & To know the doctors name & 158 & 80.6 & 38 & 19.4 \\
\hline 2 & To know the doctor's qualification & 100 & 51 & 96 & 49 \\
\hline 3 & To know the approx. length of stay & 97 & 49.5 & 99 & 50.5 \\
\hline 4 & To know the expected treatment cost & 118 & 60.2 & 78 & 39.8 \\
\hline 5 & To know the health condition & 133 & 67.9 & 63 & 32.1 \\
\hline 6 & $\begin{array}{l}\text { To be informed about treatment } \\
\text { complication }\end{array}$ & 103 & 52.6 & 93 & 47.4 \\
\hline 7 & To be informed plan of care & 127 & 64.8 & 69 & 35.2 \\
\hline 8 & To choose treatment & 81 & 41.3 & 115 & 58.7 \\
\hline 9 & To give informed consent & 86 & 43.9 & 110 & 56.1 \\
\hline 10 & To know health prognosis & 67 & 34.2 & 129 & 65.8 \\
\hline 11 & $\begin{array}{c}\text { Seen the patients' rights board } \\
\text { displayed }\end{array}$ & 101 & 51.5 & 95 & 48.5 \\
\hline 12 & $\begin{array}{l}\text { Right to privacy and confidentiality of } \\
\text { patient information }\end{array}$ & 78 & 39.8 & 118 & 60.2 \\
\hline 13 & $\begin{array}{c}\text { To give feedback about treatment } \\
\text { process }\end{array}$ & 75 & 38.3 & 121 & 61.7 \\
\hline 14 & $\begin{array}{l}\text { To give complaints of treatment } \\
\text { process }\end{array}$ & 88 & 44.9 & 108 & 55.1 \\
\hline 15 & $\begin{array}{c}\text { To be informed about inpatient } \\
\text { charges }\end{array}$ & 142 & 72.4 & 54 & 27.6 \\
\hline 16 & $\begin{array}{l}\text { To be informed deposit amount } \\
\text { required }\end{array}$ & 146 & 74.5 & 50 & 25.5 \\
\hline 17 & $\begin{array}{l}\text { To be informed to submit the details } \\
\text { of Insurance }\end{array}$ & 97 & 49.5 & 99 & 50.5 \\
\hline 18 & $\begin{array}{c}\text { To know about the medication } \\
\text { administered }\end{array}$ & 77 & 39.3 & 119 & 60.7 \\
\hline 19 & $\begin{array}{l}\text { To be informed about healthcare } \\
\text { infection and its prevention }\end{array}$ & 108 & 55.1 & 88 & 44.9 \\
\hline 20 & $\begin{array}{l}\text { To diet counselling } \\
\end{array}$ & 161 & 82.9 & 35 & 17.1 \\
\hline 21 & Be educated to prevent falls & 190 & 100 & 0 & 0 \\
\hline
\end{tabular}

Table 4. Responses of Participants to the Patient Rights Questionnair

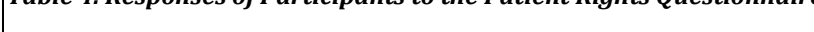

\section{DISCUSSION}

Patients' right has recently become the national centre of consideration in the practice of medicine, and these are diverse in many countries and jurisdictions according to social and cultural norms. . It appears that it is essential to assess the patients' awareness with regard to their rights and if they have received an examination compatible with their rights charter. In other studies, done in Saudi Arabia and Singapore Found that, the majority of participants were of young or middle-aged group as, in the present study most participant were adult (1835) followed by Older adult (36-59) with percentage of $53.6 \%$ and $34.7 \%$ respectively. ${ }^{19,20}$ Study done in India shows that almost all the participants (97.4\%) were aware about their doctor's name, this was in contrast in a study done in Riyadh, Saudi showed almost $97.3 \%$ did not know name of their health care providers. In our study majority of the patients, i.e., 80.6 $\%$ of the participant knew their doctor's name only $19.4 \%$ of participant did not know. Majority of patients know their doctors name may be due to the doctors introduce themselves to the patients but in case of patient knowing their doctor's qualification half of the patients did not knows their doctors qualification $49 \% .51 .5 \%$ of the participant had seen the patients' rights board put up in the hospital premises but only $39.8 \%$ of the participants were aware about their rights. In a study done in Sari, Iran it was observed that majority i.e. $63.4 \%$ of the patients had not seen the "patients' rights board." 21 Another study's also validated these findings. ${ }^{22}$ In similarity, in a study conducted in Egypt found that about 75\% of the patients had no knowledge about rights. According to the patients' rights charter by disease management association of India, patients have all the rights to have complete information about the expected cost of the treatment whereas only $60.2 \%$ of the participants were informed about their expected cost of the treatment by their doctors. In contrast to this another study done in India stated that only $42 \%$ of study participants were informed about their expected cost of the treatment by their healthcare providers. ${ }^{23}$

In this study only $43.9 \%$ of participants was aware about the informed consent. A study done in Poland, at a tertiary university hospital showed $42.9 \%$ awareness in relation to informed consent. In contrast study done in India shows that $67.7 \%$ study participants were aware about the informed consent. In this study only $49.5 \%$ of participants was aware about the approx. length of stay in hospital, study conducted in India and Malaysia, shows that more than half 54.9\% and 65\% of the patients were informed about their duration of the treatment. ${ }^{23}$ Patient's gender, age, education and marital status are the factors that show significant difference in awareness of rights and education. In the present study, males and females were almost equally aware about their rights and all the 21 components were statistically insignificant this shows that knowledge about patient's rights does not dependent's on gender of person. However, studies from India state that males were more aware about their rights than females. ${ }^{23}$

People with higher education tends to have more awareness due to their pre-knowledge and more knowledgeseeking behaviour, from our study we conclude that education of patients is directly related to the awareness about patients' rights. Components from 1-3, 5-9, 11, 12 \& 15-17 show statistically significant relation; this was comparable with study findings from Turkey in which they do a hospital survey in south Egypt for knowing patients' rights, another study from India also revels the same results. ${ }^{23}$ Patients belonging to higher economic condition choose better ward categories resulting in better information assimilation from health care 
workers as a result of lesser workload burden on health care givers. From our study we found out that about $82.14 \%$ (161) study participant were admitted to General Ward and only $17.85 \%$ (35) participants were from Private ward. Patients may have more autonomy in urban compared to rural areas. Most of the patients from our study belonged to rural area $61.73 \%$ (121) as compared to urban area $38.26 \%$ (75). In similarity the results from other study done in India, in which out of 350 study participants 211 belongs to rural and 139 belongs to urban area respectively. 23 This may be because the urban area have more numbers of private and tertiary care hospitals compared to rural areas, due to better socioeconomic conditions they might prefer private clinics than tertiary care hospitals.

\section{Limitations}

The questions asked in various domains were limited as the total number of questions asked was 21, which took around 20-25 min to answer. Patients would have found it difficult to fill it due to insufficient time. Some even refused to fill. So, the relatively small sample size might have led to inconclusive results. We did not explore the possible causes of low Awareness among indoor patients "of a tertiary care teaching hospital in Wardha."

\section{CONCLUSIONS}

There is a need for raising knowledge and awareness among patients about their right. Along with the patients' rights they should know about their responsibilities in the hospital. Brochures or pamphlets in local language about the rights of the patients in hospital can be given to the patient and also to their family/relatives at the time of registration with due attention to the rural and illiterate population using pictorial messages and using appropriate translations of the local language. Educational advertising material, booklets and posters should be placed on public notice boards in all health centres and also in hospitals. Patient Rights Committee should be formed for capturing feedback and redressal of complaints.

\section{REFERENCES}

[1] www.who.int/genomics/public/patientrights/en.

[2] United Nations. Universal Declaration of Human Rights: 1948.

(http://www.un.org/en/documents/udhr/index.shtml, accessed 16 February 2017).

[3] World Health Organization. Basic documents, 45th edn, Supplement, October 2006. Constitution of the World Health Organization.

(http://www.who.int/governance/eb/who_ constitution_en.pdf, accessed 13 March 2017).

[4] Davati A, Seidmortaz SS, Zafarghandi N, et al. An assessment of Tehran graduated general physicians' knowledge about the charter of patients' rights. Edu Res 2012;3(4):357-61.
[5] Agrawal U, D’Souza BC, Seetharam AM. Awareness of patients' rights among inpatients of a tertiary care teaching hospital - a cross-sectional study. J Clin Diagn Res 2017;11(9):IC01-6.

[6] Joolaee S, Hajibabaee F. Patient rights in Iran: a review article. Nurs Ethics 2012;19(1):45-57.

[7] WFO. Patients' rights and citizens' empowerment: through visions to reality: joint consultation between the WHO Regional Office for Europe, The Nordic Council of Ministers and the Nordic School of Public Health, Copenhagen, Denmark 22-23 April 1999.

[8] Yakov G, Shilo Y, Shor T. Nurses' perceptions of ethical issues related to patients' rights law. Nurs Ethics 2010;17(4):501-10.

[9] World Medical Association. Declaration of Lisbon on the rights of the patient. (http://www.wma.net/en/30publications/10policies/14 /, accessed 17 February 2017).

[10] Parsa-Parsi RW. The revised declaration of Geneva: a modern-day physician's pledge. JAMA 2017;318(20):1971-2.

[11] Nsiriani Kh, Salemi S, Yazdi SN, et al. Relationship between nurses knowledge respecting the rights of their patients and rate of its observance in hospitals of Yazd in 2001. Iran J Nurs 2001;(22, 23):8-14. [In Persian]

[12] Arab M, Zarei A. Determining awareness of private hospital managers in Tehran about patient rights and it effective factors. Payesh 2009;8(1):25-30. [In Persian]

[13] Mastaneh Z, Mouseli L. Patients' awareness of their rights: insight from a developing country. Int J Health Policy Manag 2013;1(2):143-6.

[14] Joolaee S, Hajibabaee F. Patient rights in Iran: a review article. Nursing Ethics 2012;19(1):45-57.

[15] Abedi G, Shojaee J, Moosazadeh M, et al. Awareness and observance of patient rights from the perspective of Iranian patients: a systematic review and meta-analysis. Iranian Journal of Medical Sciences 2017;42(3):227-34.

[16] Merakou K, Dalla-Vorgia P, Garanis-Papadatos T, et al. Satisfying patients' rights: a hospital patient survey. Nurs Ethics 2001;8(6):499-509.

[17] Sankar P, Mora S, Merz JF, et al. Patient perspectives of medical confidentiality. J Gen Intern Med 2003;18(8):659-69.

[18] Parsania M, Goodarzi M, BabaeiGh. Evaluation of nurses' knowledge about patient rights working in Karaj hospitals. J Med Sci Islamic Azad Univ Mashhad 2007;3(4):216-22. [in Persian]

[19] Habib FM, Al-Siber HS. Assessment of awareness and source of information of patients' rights: a cross-sectional survey in Riyadh Saudi Arabia. Am J Res Commun 2013;1(2):1-8.

[20] Yousuf RM, Fauzi AR, How SH, et al. Hospitalized patients' awareness of their rights: a cross-sectional survey from a tertiary care hospital on the east coast of peninsular Malaysia. Singapore Med J 2009;50(5):494-9.

[21] Zakariya AM, Aman R, Hafizullah M. Patient awareness survey in a tertiary care hospital. JPMI 2008;22(4):266-9. 
[22] Zeina HAA, El Nouman AA, Zayed MA, et al. Patients rights: a hospital survey in South Egypt. Journal of Empirical Research on Human Research Ethics: An International Journal 2013;8(3):46-52.
[23] Ghooi RB, Deshpande SR. Patients' rights in India: an ethical perspective. Indian Journal of Medical Ethics 2012;9(4):277-81. 